\title{
Over gewichtige zaken
}

Citation for published version (APA):

van Baak, M. A. (2014). Over gewichtige zaken: Afscheidsrede van Prof. Dr. Marleen A. van Baak. (1 ed.) Universiteit Maastricht. https://doi.org/10.26481/spe.20141212mb

Document status and date:

Published: 01/01/2014

DOI:

10.26481/spe.20141212mb

Document Version:

Publisher's PDF, also known as Version of record

\section{Please check the document version of this publication:}

- A submitted manuscript is the version of the article upon submission and before peer-review. There can be important differences between the submitted version and the official published version of record.

People interested in the research are advised to contact the author for the final version of the publication, or visit the DOI to the publisher's website.

- The final author version and the galley proof are versions of the publication after peer review.

- The final published version features the final layout of the paper including the volume, issue and page numbers.

Link to publication

\footnotetext{
General rights rights.

- You may freely distribute the URL identifying the publication in the public portal. please follow below link for the End User Agreement:

www.umlib.nl/taverne-license

Take down policy

If you believe that this document breaches copyright please contact us at:

repository@maastrichtuniversity.nl

providing details and we will investigate your claim.
}

Copyright and moral rights for the publications made accessible in the public portal are retained by the authors and/or other copyright owners and it is a condition of accessing publications that users recognise and abide by the legal requirements associated with these

- Users may download and print one copy of any publication from the public portal for the purpose of private study or research.

- You may not further distribute the material or use it for any profit-making activity or commercial gain

If the publication is distributed under the terms of Article $25 \mathrm{fa}$ of the Dutch Copyright Act, indicated by the "Taverne" license above, 
prof.dr. Marleen A. van Baak Faculty of Health, Medicine and Life Sciences

\section{Over gewichtige zaken}


Mijnheer de prorector,

leden van de corona,

collega's, familie en vrienden

Geachte aanwezigen

Vandaag is dan toch het moment gekomen dat ik door middel van dit college afscheid ga nemen van de Universiteit Maastricht. Ik heb er inmiddels ruim 35 jaar bij de Universiteit Maastricht opzitten en ben ruim 40 jaar actief geweest in het wetenschappelijk onderzoek. Dat nodigt uit tot terugkijken, maar ook tot vooruitkijken.

Hoe divers dat onderzoek in al die jaren is geweest wordt geïllustreerd door de titels van mijn eerste $[1,2]$ en tot nu toe laatste publicaties $[3,4]$. De allereerste publicatie ging over de inbouw van vetachtige stoffen in mitochondriën van rattenlevers [1, 2]. Mijn bijdrage bestond uit één van de figuren in het artikel. De tweede artikel was het eerste dat echt van mijn hand was en ging over het energiegebruik tijdens recreatief fietsen [2]. Op de laatste twee publicaties kom ik later terug. Tussen die eerste en laatste publicaties ligt een enorme diversiteit aan onderzoek, maar erop terugkijkend is vanaf mijn promotieonderzoek een gezonde leefstijl steeds het overkoepelende thema geweest.

\section{Over gewichtige zaken}

Ik ga in dit college een aantal 'gewichtige zaken' bespreken. Dat betekent gewoon dat ze met lichaamsgewicht te maken hebben. Ik hoop niet dat de titel van dit verhaal bij $U$ meer verheven verwachtingen heeft gewekt. Dat het over gewicht gaat zal niemand verbazen, want de laatste 25 jaar heb ik me immers vooral bezig gehouden met fysiologie van obesitas, het onderwerp van mijn leerstoel. 
Mij wordt de laatste tijd nogal eens gevraagd wat die 25 jaar nu echt aan vooruitgang heeft laten zien op het gebied van de preventie en behandeling van overgewicht. Het aantal mensen met overgewicht neemt immers nog steeds toe en de behandeling van obese mensen lijkt tot nu toe ook niet heel erg succesvol. Ik ben het met die criticasters eens dat we de magische knop om die trend te kunnen doorbreken nog niet echt hebben kunnen indrukken, maar onze kennis over de determinanten van overgewicht en succesvolle interventies om overgewicht te voorkomen en te behandelen is de afgelopen 25 jaar enorm toegenomen. En als we in staat zijn al die kennis op een geïntegreerde manier toe te passen, dan zouden we al heel wat kunnen bereiken, ik kom daar aan het einde van mijn college op terug. Dit podium biedt mij in ieder geval de gelegenheid om $u$ te laten zien dat het wetenschappelijk onderzoek naar obesitas wel degelijk nieuwe inzichten heeft opgeleverd en ik zal dat doen aan de hand van voorbeelden van onderzoek waarbij ik zelf de afgelopen jaren betrokken ben geweest.

Maar ik begin, zoals dat tegenwoordig hoort, met mijn disclosures: ik heb er geen die ik relevant acht voor het verhaal dat ik hier ga vertellen. Door de jaren heen hebben verschillende financiers mijn onderzoek mogelijk gemaakt, zoals de universiteit, NWO, collectebusfondsen en het bedrijfsleven. Marianne Geleijnse van Wageningen Universiteit vertelde afgelopen oktober op de Nutritional Science Days, dat ook je body mass index voor de invulling van je onderzoek, de kleuring van de interpretatie daarvan en hoe je dat naar buiten brengt van belang kan zijn en misschien nog wel belangrijker is dan je samenwerkingen met allerlei industriën. Ik meld $u$ dus nu alvast dat mijn body mass index beneden de $25 \mathrm{~kg} / \mathrm{m}^{2}$ ligt, dat is de grens tussen normaal gewicht en overgewicht. Ik val dus niet binnen de groep mensen waar het 
grootste deel van mijn onderzoek zich de afgelopen jaren op heeft gericht. Hoe dat mijn verhaal vandaag kleurt weet ik niet, maar de vraag hoe het toch mogelijk is dat sommige mensen in onze maatschappij totaal geen problemen hebben met hun gewicht, terwijl anderen er voortdurend mee worstelen heeft me altijd geïntrigeerd en doet dat, zoveel jaar later en veel kennis wijzer, nog steeds. Daar gaat het eerste deel van mijn college dan ook over.

\section{Over fysiologie van obesitas}

Mijn vakgebied is dus de fysiologie. De fysiologie is de wetenschap die bestudeert hoe orgaansystemen, organen, cellen en biomoleculen de chemische en fysische functies uitoefenen in een levend organisme. In mijn geval is dat levende organisme de mens en meer in het bijzonder de mens die te zwaar is of dreigt te worden. Een van de belangrijkste begrippen in de fysiologie is dat van homeostase en een belangrijk onderwerp van onderzoek zijn de regelsystemen in het lichaam om die homeostase te bewaren. Denk daarbij bijvoorbeeld aan de temperatuurregulatie of de bloeddrukregulatie. Ook het lichaamsgewicht lijkt op de een of andere manier gereguleerd te worden. Om dat te illustreren wordt vaak de volgende rekensom gemaakt, ik neem mezelf maar even als voorbeeld : toen ik 20 was woog ik 62 kilo en op dit moment is dat ongeveer 64 kilo. Dat betekent dat er in 45 jaar een verschil tussen energie-inname en energiegebruik is geweest van ongeveer 14.000 kilocaloriën. Dat is namelijk ongeveer de energie-inhoud van 2 kilo vet. Met een energieinname van rond de $2000 \mathrm{kcal}$ per dag, komt dat neer op een verschil van nog geen kilocalorie per dag tussen energie-inname en energiegebruik over die 45 jaar, een schijnbaar verbijsterende nauwkeurigheid. Maar die nauwkeurigheid is inderdaad schijnbaar, want je gewicht is van dag tot dag minder constant dan waarvan hier wordt uitgegaan. De figuur illustreert dat. 


\section{Gewichtsverloop van dag tot dag}

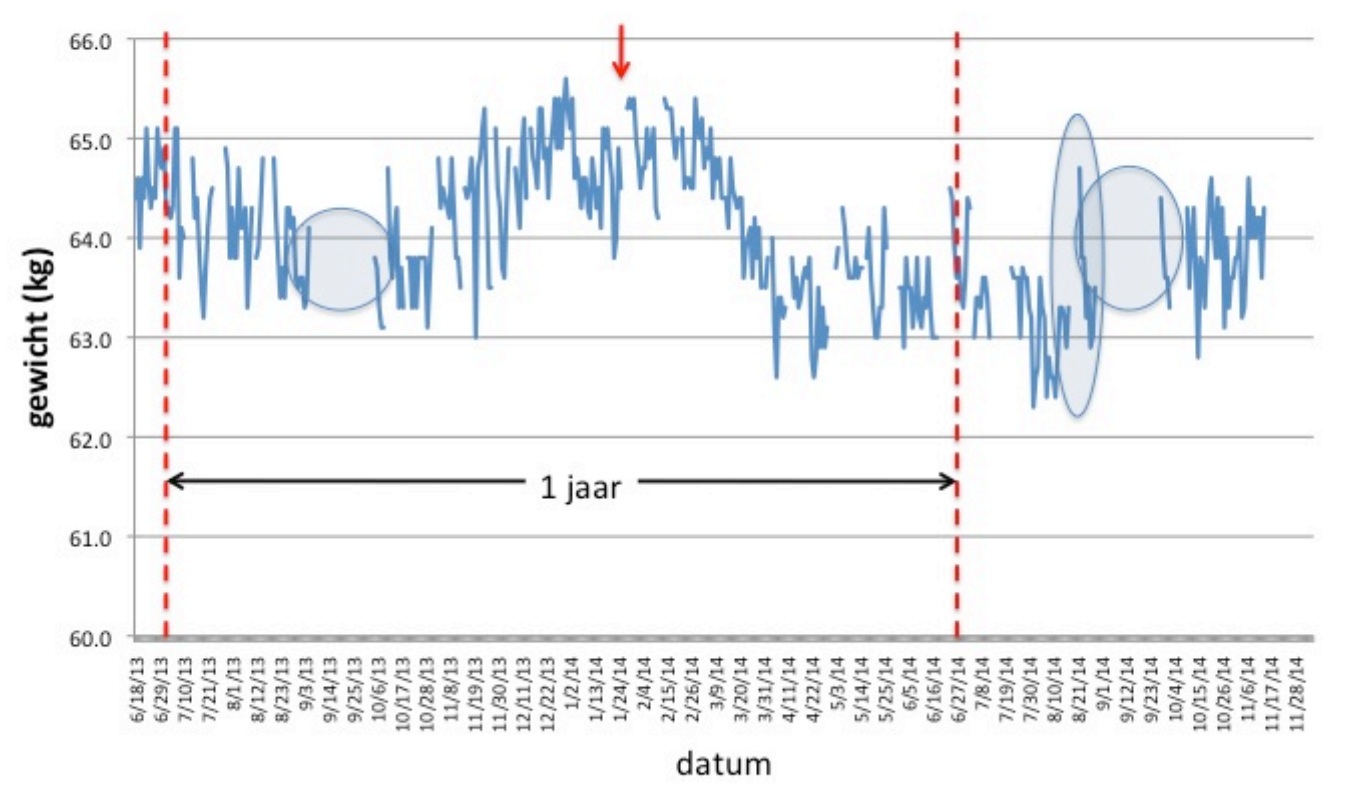

Het gewicht van deze persoon is gedurende ongeveer anderhalf jaar iedere dag gemeten. Je kunt mooi de seizoensinvloed zien, mensen zijn 's winters gemiddeld wat zwaarder dan 's zomers. $U$ had het misschien al vermoed, maar dit is mijn eigen gewichtsverloop. Ik heb eigenlijk tot ik hieraan begon zelden of nooit op de weegschaal gestaan. Maar ik moet zeggen, het is wel enigszins verslavend. De reden om eraan te beginnen was, dat ik benieuwd was wat pensionering zou doen met mijn gewicht, waarom zal ik later in dit college duidelijk maken. De pijl geeft de datum aan dat ik officieel met pensioen ben gegaan, al enige tijd geleden, dus dit afscheid komt een beetje laat. Zoals u ziet ging mijn gewicht daarna wat naar beneden, maar of dat gewoon het seizoen was of iets meer vrije tijd en activiteit is natuurlijk lastig vast te stellen. Misschien nog wat andere details: de cirkels zijn twee vakanties, de één een fietsvakantie naar Rome met een heel hoog niveau van activiteit, de andere een safarivakantie in Afrika met een extreem laag niveau van activiteit. En voor een aantal insiders hier in de zaal: de ellips 
weerspiegelt het effect van een week fietsen met een bourgondisch ingesteld gezelschap.

Tot zover dit intermezzo, terug naar de echte wetenschap.

\section{Over gewichtsregulatie}

Ook al is de regulatie van het lichaamsgewicht niet zo nauwkeurig als ik eerder voorrekende, er zijn desondanks veel aanwijzingen voor de aanwezigheid van een regelsysteem voor het lichaamsgewicht. Op grond van dierstudies werden daar al in de jaren 50 van de vorige eeuw verschillende modellen voor ontwikkeld. Een daarvan was het lipostatische model van Kennedy uit 1953 [5], waarbij het vetweefsel signalen afgeeft naar de hersenen over de in het vet aanwezige energievoorraad. Is er veel vet, dan is de reactie dat de energie-inname wordt verkleind en het energiegebruik wordt verhoogd. Is er weinig vet, dan vindt het omgekeerde plaats. Lange tijd was onduidelijk wat het signaal van vetweefsel naar hersenen was, dat in dit model een essentiële rol speelt. Pas in 1994 werd dit eiwit ontdekt door Jeffrey Friedman en in 1995 werd de werking ervan op de voedselinname bij muizen aangetoond en kreeg het zijn naam, leptine (van het Griekse leptos dat verzadiging betekent) [6].

Een van mijn meest geciteerde publicaties is nog altijd die over een onderzoek dat Dorien van Aggel kort na de ontdekking van leptine heeft gedaan naar de invloed van veranderingen in de energiebalans op de leptineconcentraties in het bloed [7]. Die studie 


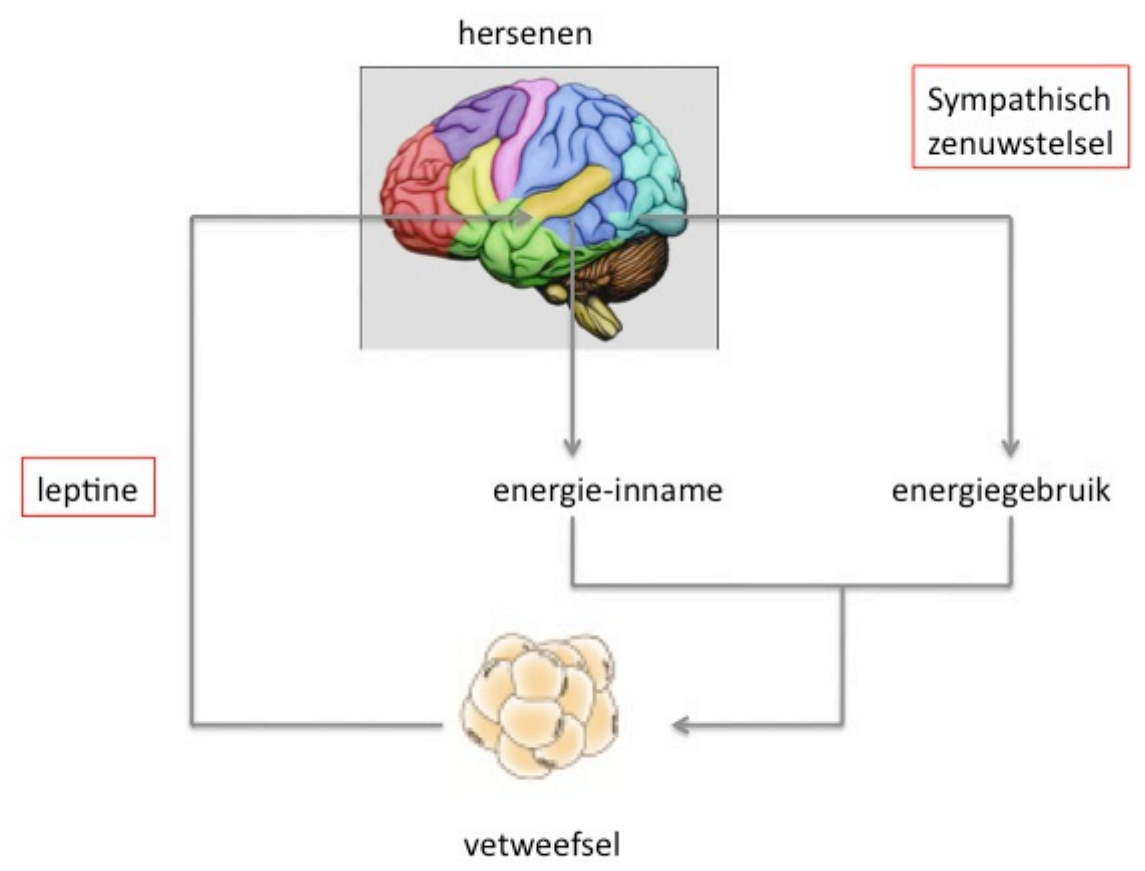

liet zien dat overvoeden bij mensen inderdaad, zoals het model voorspelt, leidt tot een stijging van de leptineconcentraties in het bloed en ondervoeding tot een daling, maar dat die veranderingen pas 's nachts zichtbaar zijn. Het was een beetje een lucky shot dat we ook 's nachts hebben gemeten. Hadden we alleen overdag gemeten, dan was er niets te zien geweest. Dus het nachtenlang opblijven van de onderzoekers werd in dit geval gelukkig beloond. Het grootste deel van mijn onderzoek heeft zich echter niet op leptine, maar op de efferente arm van dit regelmechanisme gericht, namelijk op de rol van het sympathisch zenuwstelsel en met name het beta-adrenerge deel daarvan. Het sympathisch zenuwstelsel stimuleert de beta-receptoren in de spier waardoor het energiegebruik in de spieren stijgt. Om die energie te kunnen leveren moeten vetten geoxideerd worden. Daarvoor worden de vetzuren gebruikt die gelijktijdig door beta-adrenerge stimulering uit het vetweefsel worden vrijgemaakt. 
In een flink aantal studies van Ellen Blaak en daarna Sandra Schiffelers hebben we laten zien dat mensen met overgewicht ongevoeliger zijn voor een verhoogde beta-adrenerge aktiviteit en dat dat vooral samenhangt met een verminderde gevoeligheid van één van de subtypen van de beta-receptoren, de beta 2 -receptor, die zowel in de spier als in het vetweefsel voorkomt [8,9].

Als je minder gevoelig bent voor beta-adrenerge stimulering betekent dat dus dat eenmaal opgeslagen vet minder gemakkelijk weer afgebroken en verbrand wordt. Dat helpt op zijn minst om overgewicht en obesitas in stand te houden. De grote vraag is natuurlijk of deze verminderde gevoeligheid een oorzaak of een gevolg is van de vergrote vetmassa. Ellen Blaak heeft in haar onderzoek nog in de jaren 90 laten zien dat afvallen de gevoeligheid voor stimulering niet vergroot [10], Joost Oomen heeft laten zien dat mogelijk mutaties in het DNA een rol spelen bij verschillen in gevoeligheid tussen mensen [11], en recent heeft Karianna Teunissen nog eens heel specifiek in geïsoleerde vetcellen van obese mensen naar de verandering in gevoeligheid van de beta ${ }_{2}^{-}$ receptor onder invloed van gewichtsverlies en ten gevolge van training gekeken. In beide gevallen waren er geen veranderingen in de gevoeligheid van die receptor (nog niet gepubliceerd).

Met het (weer) in de belangstelling komen van het humane bruin vet zo'n 5 jaar geleden, werd de vraag actueel of een deel van de effecten van beta-adrenerge stimulering op het energiegebruik misschien zou kunnen verlopen via de aktivering van bruin vetweefsel, omdat bekend is dat bijvoorbeeld tijdens koudeblootstelling de activering van bruin vet via een verhoogde beta-adrenerge activiteit verloopt. Dat leidt tot warmteproductie in het bruine vet en een verhoogd energiegebruik. Maarten Vosselman, een aio van mijn collega Wouter van Marken Lichtenbelt, een van de pioniers in deze bruin vet revival, heeft een studie gedaan waarin hij heeft gekeken of het toedienen van een 
beta-agonist, dat is een stof die de beta-receptoren stimuleert, bruin vet bij mensen activeert. Dat bleek niet het geval. Koude induceerde bruin vetactiviteit, maar toediening van de beta-agonist isoprenaline niet [12]. Wel was het energiegebruik na toediening van de beta-agonist verhoogd, net als wij dat in onze eerdere studies hadden aangetoond. Dus in ons onderzoeksmodel lijkt bruin vet geen rol te spelen. Dat sluit uiteraard een rol van bruin vet in de fysiologie van obesitas geenszins uit en daar wordt nog volop onderzoek naar gedaan op dit moment.

Mijn conclusie uit deze lange reeks studies is dat bij mensen die overgewicht ontwikkelen een verminderde gevoeligheid voor betaadrenerge stimulatie een rol kan spelen.

Heeft dit alles praktische consequenties voor de preventie en behandeling van obesitas? Een relevante vraag, want de valoriseerbaarheid van wetenschappelijk onderzoek is tegenwoordig een belangrijk aandachtspunt binnen universiteiten. Ik hoef er gelukkig geen 5 pagina's aan wijden, zoals onze huidige promovendi dat moeten in hun proefschrift, maar een logische optie voor obesitasbehandeling lijkt het toedienen van beta-agonisten. Ik weet dat dat ook wel eens op kleine schaal is uitgeprobeerd en volgens de betrokken arts met enig succes wat betreft het gewicht. Hoewel dus een logische optie, stuit behandeling met de op dit moment beschikbare beta-agonisten in de praktijk op teveel bezwaren gezien de alom-aanwezigheid van beta-receptoren in het lichaam, waardoor de bijwerkingen onacceptabel zijn. Op dit moment lijkt dit een doodlopende weg, maar mogelijk dat in de toekomst nog andere aangrijpingspunten voor medicamenteuze behandeling in dit regelsysteem worden gevonden.

De fysiologische betekenis van leptine lijkt vooral te liggen in het detecteren van situaties van negatieve energiebalans en het beschermen van het lichaam tegen te lage energievoorraden [13]. 
Leptinetoediening heeft heel goede resultaten bij de behandeling van kinderen die extreem obees worden tengevolge van een zeldzaam defect in het leptinegen, waardoor ze zelf geen leptine kunnen aanmaken. "Gewone" obese mensen produceren juist veel leptine door hun hoge vetmassa, maar zijn ongevoelig voor de werking ervan. Daardoor werkt leptinetoediening bij hen niet. Op dit moment wordt gezocht naar zogenaamde leptine sensitizers, die de gevoeligheid voor leptine zouden kunnen vergroten [14]. Je kan dat vergelijken met de insuline sensitizers (de thiazolidinediones) zoals die bij de behandeling van type 2 diabetes gebruikt worden. De toekomst zal moeten uitwijzen of dat een begaanbare weg is.

Het lipostatische model zoals ik dat eerder heb geschetst is duidelijk veel te beperkt. Er zijn veel meer biologische factoren die invloed hebben op de regulering van het gewicht. Bovendien wordt geen rekening gehouden met gedrags- en omgevingsinvloeden die ook een rol spelen. Er zijn tegenwoordig dan ook andere modellen die proberen ook die invloeden mee te nemen en de manier warop ze in interactie zijn met biologische regelmechanismen [5]. Een daarvan is het model dat de gewichtsregulatie voorstelt als een meer waarin water binnenstroomt ten gevolge van regenval en dat een passieve uitstroom heeft. De regen staat in dit model voor de voedselinname, de uitstroom voor het energiegebruik en het waterhoeveelheid in het meer voor de vetmassa. Als het harder gaat regenen, stijgt de spiegel van het water net zolang tot er weer een evenwicht ontstaat tussen instroom en uitstroom. Uitgaande van dit model, zou je kunnen stellen dat de verminderde betaadrenerge gevoeligheid bijdraagt aan het verhogen van de uitstroomdrempel van het meer, zodat de inhoud van het meer (de vetmassa) verder stijgt bij een bepaalde voedselinname voor een evenwicht wordt bereikt. Ook andere factoren, niet alleen van biologische aard, zoals gedrags- en omgevingsfactoren, kunnen de 
mate van instroom (hoeveelheid regen) en de uitstroomdrempel beïnvloeden. Voorbeelden daarvan zijn de alom aanwezigheid van een grote variëteit aan bewerkte voedingsmiddelen die vaak calorierijk zijn en veel vet en suiker bevatten, die we over het algemeen lekker vinden, waarvoor veel reclame wordt gemaakt en die ook nog eens goedkoop zijn ten opzichte van meer gezonde producten, te grote porties, tegenstrijdige informatie in de media, ongezonde gewoontes, een gebouwde omgeving die niet uitnodigt tot lichamelijke activiteit, een sociale omgeving die het moeilijk maakt er een gezonde leefstijl om na te houden, etcetera.

Deze nieuwere modellen zijn in staat ook dit soort factoren te incorpereren. En dat moet ook, want als er iets de laatste jaren is duidelijk geworden dan is het dat obesitas niet één oorzaak heeft, maar een extreem multifactoriële aandoening is, waarvan de factoren in verschillende combinaties en verhoudingen bij obese individuen kunnen voorkomen. Daardoor is obesitas een zeer complexe aandoening die ongelofelijk moeilijk te voorkomen en ook te behandelen is.

\section{Over preventie en behandeling}

In het tweede deel van dit college wil ik ingaan op die preventie en behandeling van overgewicht.

Wetenschappelijk onderzoek naar het voorkomen van gewichtsstijging in mensen met een normaal gewicht via interventies is ontzettend lastig. Je hebt grote groepen deelnemers nodig die je langdurig volgt om effecten te kunnen aantonen, omdat op groepsniveau de gemiddelde gewichtsstijging maar erg klein is. Bovendien is het erg moeilijk om de juiste doelgroep te bereiken. Hoe interesseer je mensen die (nog) geen probleem hebben met hun gewicht voor interventies om een mogelijk toekomstig gewichtsprobleem te voorkomen. 
Ik zal dat illustreren aan de hand van een voorbeeld uit ons eigen onderzoek. We hebben zo'n 10 jaar geleden samen met onderzoekers uit Amsterdam en Wageningen onder leiding van professor Daan Kromhout het NHF-NRG project gedaan naar het voorkomen van gewichtsstijging in drie levensfasen waar het risico op gewichtsstijging het grootst is: rond de puberteit, in jong volwassenen en in mensen rond hun pensionering. Daar komt dus mijn interesse in mijn gewichtsverloop in die fase vandaan. Wij hebben vanuit Maastricht het onderdeel jong volwassenen uitgevoerd, het InBalance project met Lydia Kwak als aio, waarbij we mensen tussen de 25 en 35 jaar via hun werkplek adviezen op maat hebben gegeven over een gezonde leefstijl (voeding en beweging) met als doel gewichtsstijging te voorkomen. Een van de problemen bij deze studie was de werving van deelnemers binnen de bedrijven. De werknemers die aan de studie mee wilden doen waren over het algemeen wat ouder, wat zwaarder en wat hoger opgeleid dan de gemiddelde werknemer in die bedrijven. Je zou dat kunnen interpreteren als dat we meer mensen recruteerden die zich zorgen maakten over hun gewicht en meer bereid waren daar wat aan te doen. De resultaten van het onderzoek waren op zich redelijk positief. Na 1 en 2 jaar daalde de middelomtrek en de vetmassa van de interventiegroep meer dan die in de controlegroep, al waren er geen verschillen in gewichtsverandering [15]. We konden niet aantonen dat we gewichtsstijging konden voorkomen in deze jong volwassenen, want in beide groepen ging het gewicht omlaag en niet omhoog.

Dat je in onderzoek soms niet de doelgroep bereikt die je interventie het hardst nodig heeft, is een bekend probleem in veel academisch interventieonderzoek. Zo is in het verleden in Maastricht onder leiding van Ellen Blaak de SLIM studie uitgevoerd. Dat was een leefstijlinterventie in prediabeten, die meestal ook 
overgewicht hebben. De interventie was effectief, het risico op het ontwikkelen van type 2 diabetes werd gedurende de 6 jaar dat het onderzoek heeft gelopen gereduceerd ten opzichte van de controlegroep. Uit analyse van de deelnemers bleek dat er ook hier relatief weinig mensen met een lage sociaal-economische status deelnamen aan het onderzoek en dat zij bovendien vaker tot de uitvallers behoorden [16]. Juist in de bevolkingsgroep met een lage SES komt overgewicht en de complicaties daarvan veel voor en de vraag was dan ook hoe je dit soort interventies aantrekkelijker zou kunnen maken voor deze doelgroep.

Dat is de inzet van een onderzoek dat we op dit moment in het kader van het "Lekker Lang Leven" programma van Diabetesfonds, Hartstichting en Nierstichting samen met Edith Feskens van Wageningen Universiteit uitvoeren. Eén van de laatste publicaties die ik eerder noemde was afkomstig uit dit project [3]. Het project behelst de aanpassing van de SLIM interventie voor mensen met een lage SES met verschillende ethnische achtergronden. In dit project richten we ons op mensen met een Nederlandse, Turkse en Marokkaanse achtergrond. Via focusgroepgesprekken met de doelgroep is geprobeerd te achterhalen aan welke eisen een SLIMachtige leefstijlinterventie zou moeten voldoen wil die aantrekkelijk voor hen zijn en hoe de werving van deelnemers het beste zou kunnen plaatsvinden. Dit heeft geleid tot een aantal aanpassingen in de oorspronkelijke SLIM interventie, waarvan de belangrijkste zijn: werving van deelnemers niet via algemene oproepen of advertenties, maar via een vetrouwde persoon (bij voorkeur de huisarts) of via direct persoonlijk contact in een bekende omgeving (bv. wijkcentrum); interventie in de buurt in plaats van in een universitaire setting; individueel voedingsadvies door een op ethniciteit gematchte diëtiste en veel meer naar behoefte verspreid over het jaar in plaats van op vaste tijdstippen; het beweegprogramma voor mannen en vrouwen gescheiden 
organiseren met gender-gematchte instructeurs; de mogelijkheid om een buddy mee te nemen naar alle activiteiten (Teuscher, Bukman et al., in voorbereiding). Op dit moment wordt de aangepaste interventie uitgevoerd in sociaal zwakke buurten in Arnhem en Eindhoven, volgend jaar hopen we de ervaringen en de resultaten te kunnen presenteren.

\section{Over obesitasbehandeling}

Dan de behandeling van obesitas. In een artikel uit 1989, toen ik dus begon met het obesitasonderzoek, van George Bray, een van de nestors van het obesitasonderzoek van de afgelopen periode stond deze zinsnede: "Obesity is a chronic condition, which can be palliated, but only rarely cured. Recidivism, that is regain of weight once lost, occurs in the majority of individuals who enter a treatment program" [17]. Dat klonk toen weinig hoopvol. Zijn we sindsdien wat opgeschoten of is dit nog steeds zo? Ik denk dat we zeker zijn opgeschoten en ik zal daar wat voorbeelden van geven. George Bray noemde "jaw-wiring" nog als één van de serieuze behandelopties. Het lijkt gelukkig achterhaald, maar restrictieve behandeling van obesitas is zeker niet achterhaald: immers de bariatrische chirurgie is de afgelopen jaren steeds verder ontwikkeld voor de behandeling van de ernstigere vormen van obesitas en biedt ook goede lange termijn resultaten [18].

In onderzoek naar geneesmiddelen voor de behandeling van obesitas is in de afgelopen 25 jaar heel wat geïnvesteerd, en we hebben zelf ook een aantal trials op dat gebied gedaan. Al dat onderzoek heeft niet geleid tot een echte doorbraak. De afgelopen jaren zijn met enige regelmaat nieuwe gewichtsreducerende geneesmiddelen op de markt geïntroduceerd, maar de meeste daarvan zijn ook relatief snel weer verdwenen vanwege een problematisch bijwerkingenprofiel. Op dit moment is er wereldwijd een klein aantal geneesmiddelen op de markt die ingezet kunnen 
worden als ondersteuning van de reguliere obesitasbehandeling die gebaseerd is op energiebeperking en het stimuleren van beweging en het ondersteunen van die gedragsverandering. In Nederland is alleen orlistat op dit moment voor dit doel beschikbaar. Het levert een extra gewichtsverlies van zo'n $3 \mathrm{~kg}$ bovenop het effect van de reguliere behandeling. Maar ook orlistat heeft de nodige, vooral gastro-intestinale, bijwerkingen. Bovendien wordt de behandeling niet vergoed.

Hoe effectief is tegenwoordig de reguliere obesitasbehandeling gebaseerd op leefstijlverandering? In een review van lange-termijn resultaten van verschillende soorten reguliere obesitasbehandelingen uit 2007 is te zien dat er weliswaar altijd weer gewichtstoename optreedt na het initiële gewichtsverlies, maar ook dat het gewicht na 4 jaar in de meeste gevallen nog steeds gemiddeld zo'n 4-8 kg lager is dan het gewicht voor aanvang van de behandeling [19]. Een dergelijk lange termijn gehandhaafd gewichtsverlies gaat gepaard met duidelijke gezondheidswinst. De recent gestopte Look Ahead trial in de Verenigde Staten had als primair doel het verminderen van de cardiovasculaire mortaliteit bij mensen met type 2 diabetes door middel van een intensieve leefstijlinterventie. Die leefstijlinterventie had onder meer een langdurig gehandhaafd verlies van $10 \%$ van het lichaamsgewicht tot doel. De studie geeft een mooi inzicht in de nog langere termijn effecten van dit soort interventies op het gewicht. Na 10 jaar was er nog steeds een gewichtsverlies van rond de $6 \%$ in de interventiegroep [20]. Dus dit soort interventies kan ook op veel langere termijn blijvend effectief zijn. De vraag dringt zich of er niet nog effectievere lange-termijn ondersteuning mogelijk is. $\mathrm{Nu}$ bestond de ondersteuning na het eerste jaar, waarin de interventie heel intensief was met wekelijkse bijeenkomsten, uit één contact per maand [20]. 
Wij hebben zelf de afgelopen periode het behandelprogramma van COEUR ge-evalueerd. COEUR, Centrum voor Obesitas Europa, is een bedrijf, aanvankelijk gevestigd in Heerlen, nu in Maastricht, waar mensen met obesitas gedurende 18 maanden een intensief behandelingsprogramma konden ondergaan. Het programma was gericht op blijvende gedragsverandering in de richting van een meer gezonde leefstijl en werd begeleid door artsen, psychologen, fysiotherapeuten en diëtisten. Zo'n langdurige multidisciplinaire behandeling is volgens mij inderdaad nodig om ook op lange termijn succes te kunnen hebben. Inmiddels is het programma om vooral financiële redenen over een andere boeg gegooid, zodat de gegevens die wij de afgelopen jaren hebben verzameld niet meer direct van toepassing zijn op het huidige programma. We hebben 426 achtereenvolgende cliënten van COEUR die daarvoor toestemming gaven in ons onderzoek opgenomen. Lang niet alle cliënten hebben de 18 maanden behandeling afgemaakt om allerlei, bijvoorbeeld ook financiële, redenen. Dat is inherent aan een dergelijk programma dat in de "werkelijke" wereld wordt aangeboden, maar lastig voor ons als onderzoekers. De aio op dit project, Erik Aller, is op dit moment bezig te uitkomsten grondig te analyseren, maar ik heb wat getallen over het behandelsucces bij 235 van de 426 cliënten die de behandeling 1 jaar hebben volgemaakt, ruim de helft dus, die ik met u wil delen. Bijzonder aan deze groep mensen is dat hun BMI bij aanvang $40 \mathrm{~kg} / \mathrm{m}^{2}$ was, dus dit zijn vooral mensen met ernstig overgewicht die vaak al van alles hebben geprobeerd om gewicht te verliezen. Een moeilijke groep dus. De resultaten laten zien dat ook in deze groep na een jaar een klinisch relevante gewichtsreductie van ruim $8 \%$ bereikt werd, vergelijkbaar met de Look Ahead Study en andere studies in academische settings. Daarnaast verbeterden bloeddruk, cholesterol, triglyceriden en glucose spiegels in het bloed ook allemaal significant (Aller et al., in voorbereiding). De vraag is 
natuurlijk wat er na het stoppen van de behandeling gebeurt. Ik ben er van overtuigd dat blijvende professionele ondersteuning van belang is voor een blijvend succes op nog langere termijn. Onderzoek naar wat de optimale en uiteraard kosten-effectieve vorm van die langdurige ondersteuning zou moeten zijn lijkt mij dan ook erg belangrijk en een prioriteit voor de komende jaren.

Een van de vragen waar we ons in het kader van obesitasbehandeling ook over buigen is of we kunnen voorspellen bij welke mensen behandeling meer of minder goed aanslaat. Zo hebben we gekeken naar mogelijke genetische factoren die behandelsucces voorspellen binnen het COEUR-programma. Onze eerste resultaten laten zien dat bepaalde polymorfismes in genen die betrokken zijn bij de regulering van de vetopslag en structurele aanpassingen van het vetweefsel voorspellend zijn voor de mate van succes tijdens de behandeling (Aller et al., in review). Mogelijk dat dit soort informatie in de toekomst aanknopingspunten gaat geven voor het meer op individuele eigenschappen toespitsen van de behandeling om deze nog effectiever te maken.

\section{Over gewichtshandhaving na afvallen}

Wat al het onderzoek naar de behandeling van obesitas mij heeft geleerd de afgelopen jaren is dat voor veel obese mensen niet zo zeer het afvallen op zich een probleem is, maar dat het voorkomen van terugval daarna de grootste uitdaging vormt. Eén van de vaak gehoorde adviezen die, ook door diëtisten, gegeven wordt is dat je vooral niet te snel moet afvallen, omdat je dan op lange termijn minder succesvol bent.

In een recent artikel van de hand van een internationale groep obesitasexperts werd dit als een van de mythes op het gebied van obesitas gepositioneerd [21]. De onderbouwing die door deze experts werd gegeven vond ik nog niet helemaal volledig. Ze vergelijken namelijk de gewichtsstijging na snel en minder snel 
afvallen terwijl het maximale gewichtsverlies in beide situaties heel verschillend was, namelijk veel groter bij de snelle afvallers dan bij de langzame afvallers. De snelle afvallers stijgen ook weer sneller in gewicht maar behouden op lange termijn toch een groter gewichtsverlies. Maar vaak gaan mensen een dieet volgen om een bepaalde hoeveelheid gewicht te verliezen. Maakt het dan uit of je het snel of langzaam doet? Dat heeft Roel Vink in het kader van een NWO-TOP onderzoeksproject dat ik samen met mijn collega Edwin Mariman uitvoer, onderzocht. Samen met Laura Arkenbosch als diëtiste heeft hij twee groepen obese personen snel dan wel langzaam ca. $10 \%$ van hun gewicht laten verliezen in 5 respectievelijk 12 weken. Het 5 weken dieet (VLCD) was een echt "crash" dieet, volledig door middel van vloeibare voeding, het 12 weken dieet (LCD) was minder rigoreus en was een combinatie van normale en vloeibare voeding. Daarna werd in een periode van 4 weken geleidelijk overgeschakeld op een gewoon voedingspatroon. Aan het einde daarvan was het gewichtsverlies in beide groepen gelijk. Vervolgens werden de mensen nog 9 maanden begeleid door de diëtiste, waarbij ze alleen nog adviezen kregen over een gezonde leefstijl en ze zich niet aan een bepaalde voorgeschreven calorieinname moesten houden zoals in de eerste fase. Zoals te verwachten was, nam het gewicht in de loop van die 9 maanden geleidelijk toe, maar ook in dit geval bleek er geen verschil in gewichtstoename tussen beide groepen (Vink et al., in voorbereiding). Dus inderdaad is de mythe ook wat dit aspect betreft definitief ontkracht.

Primaire vraagstelling van dit NWO-TOP onderzoeksproject van Roel Vink en Nadia Roumans, als tweede aio, is of het krimpen van vetcellen tijdens het afvallen gepaard gaat met stress van vetcellen en de extracellulaire matrix waarin zich die bevinden, waardoor de vetcel signalen gaat afgeven die de persoon aanzet tot eten om de vetcellen weer te vullen. De interventie is inmiddels afgerond. We 
hebben in deze studie bloed afgenomen vanuit een ader die afkomstig is vanuit het onderhuidse vetweefsel van de buik, zodat we de opname van stoffen in en afgifte van stoffen uit dat vetweefsel voor en na afvallen kunnen vergelijken. Verder hebben we ook vetbiopten genomen. Alle verzamelde materiaal zit in de vriezers en zal de komende tijd geanalyseerd worden. Hopelijk kunnen we aan het einde van het project iets meer zeggen over de mogelijkheid dat ook door afvallen geïnduceerde biologische factoren van invloed zijn op die schijnbaar onvermijdelijke gewichtstoename na afvallen. Met natuurlijk dan uiteindelijk de hoop dat we strategiën kunnen ontwikkelen om het risico op gewichtstoename te beperken.

Wat kunnen we nu al doen om het risico op gewichtsstijging na afvallen te beperken? In Maastricht is de afgelopen jaren veel ervaring opgedaan met de gewichtsinvloeden van eiwitinname, bijvoorbeeld door mijn collega Margriet Westerterp. Ook ik heb een aantal projecten gedaan waarbij met name naar de invloed van het eiwitgehalte van de voeding op de gewichtstoename na afvallen is gekeken. Het eerste was een kleinschalige studie, waarin Mandy Claessens heeft gekeken naar de invloed van de inname van twee verschillende eiwitsupplementen over een periode van 12 weken na een periode van afvallen. We vonden dat mensen die de eiwitsupplementen namen minder in gewicht toenamen dan mensen die koolhydraatsupplementen consumeerden [22]. Binnen het door de Europese Commissie gefinancierde DIOGENES-project, vanuit Maastricht gecoördineerd door Wim Saris, hebben we opnieuw gekeken naar de invloed van eiwitverrijkte voedingspatronen op gewichtstoename na afvallen in Europese gezinnen uit 8 verschillende landen. Dit was een hele grote studie, er deden ruim 800 volwassenen met overgewicht aan mee. De belangrijkste publicatie over de voedingsinterventie in de New England Journal of 
Medicine liet zien dat er 6 maanden na afvallen geen gewichtstoename was in de groep die een voedingsadvies volgde voor een voeding met een hoger eiwitgehalte en een lagere glykemische index en dat de gewichtstoename het sterkst was in de groep met een meer gebruikelijk eiwitgehalte en glykemische index [23]. Wij hebben recent ook de effecten na één jaar in een deel van de DIOGENESpopulatie (in Maastricht en Kopenhagen), die langer is vervolgd, geanalyseerd en daarbij vonden we dat de mensen die het voedingspatroon met het hogere eiwitgehalte volgden nog steeds minder gewichtstoename vertoonden dan de groep op het meer gebruikelijke voedingspatroon [4]. De glykemische index van de voeding kwam in deze analyse niet duidelijk als belangrijk naar voren. In het kader van een project van het Top Institute Food \& Nutrition heeft Karianna Teunissen bovendien laten zien dat een wat hogere eiwitinname bij mensen met overgewicht en een licht verhoogde bloeddruk, een combinatie die heel veel voorkomt, ook een gunstig bloeddrukverlagend effect heeft, onafhankelijk van een effect op het gewicht [24].

Wat meer eiwitten ten koste van koolhydraten lijkt dus gunstig te zijn voor mensen met overgewicht. Uiteraard moeten deze afgewogen worden tegen mogelijk andere minder gunstige gezondheidseffecten, maar in onze studies hebben we daar tot nu toe geen aanwijzingen voor gevonden.

Wat kunnen we op dit moment nog meer doen om gewichtsstijging na afvallen te voorkomen? Onlangs is een overzicht van strategiën die daarvoor getest zijn gepubliceerd [25]. Behandeling met antiobesitas geneesmiddelen, het gebruik van maaltijdvervangers en een eiwitverrijkt voedingspatroon zijn het meest effectief. Meer inspanning en voedingspatronen met andere macronutriëntensamenstellingen (lage glykemische index, laag vet, volgens nationale aanbevelingen) hadden ook effect maar minder sterk. Het 
gebruik van voedingssupplementen (zoals CLA, groene thee) had geen effect.

\section{Over waar we nu staan}

Ik heb tot nu toe een aantal voorbeelden laten zien van meer of minder succesvolle interventies waarbij ikzelf betrokken ben geweest. Maar er is natuurlijk veel meer gedaan. In november is een rapport verschenen van het McKinsey Global Institute [26] met als titel "Overcoming obesity: an initial economic analysis", waarvan ik u een aantal conclusies niet wil onthouden omdat het een redelijk overzicht geeft van waar we op dit moment staan.

Allereerst de wereldwijde omvang van het probleem: ongeveer $30 \%$ van de totale wereldbevolking is te zwaar. De economische kosten die daaraan verbonden zijn zijn vergelijkbaar met die tengevolge van roken of wereldwijd gewapend geweld. Het rapport beschrijft 74 verschillende interventies op 18 verschillende maatschappelijke terreinen die effectief zijn bij de bestrijding van overgewicht. Voorbeelden daarvan zijn maatregelen op het gebied van portiegroottes, herformulering van voedingsmiddelen, obesitasbehandelprogramma's, educatie van ouders en kinderen, reclamebeperking, etcetera. De onderzoekers hebben geschat wat implementatie van 44 van de 74 interventies in het Verenigd Koninkrijk zou opleveren: $20 \%$ van de mensen die nu overgewicht hebben zouden dan in de normale BMI categorie terechtkomen. Verder wetenschappelijk onderzoek zal er toe moeten leiden dat we niet alleen binnen de categoriën die nu al geïdentificeerd zijn effectievere interventies ontwikkelen die specifieke doelgroepen beter bereiken, maar ook dat nieuwe interventiemogelijkheden worden ontdekt. Het fysiologische obesitas-gerelateerde onderzoek, zoals dat binnen de vakgroepgemeenschap Humane Biologie/ Bewegingswetenschappen gedaan wordt en hopelijk in de toekomst voortgezet wordt, biedt daarvoor nog voldoende mogelijkheden. Ik 
hoop dat in de toekomst ook het meer interdisciplinair georiënteerde obesitasonderzoek in Maastricht een belangrijk speerpunt zal zijn. Het interfacultaire project Eatwell van de Universiteit Maastricht kan daar een goede voedingsbodem voor zijn. Want ik ben het met het McKinsey rapport eens dat alleen een geïntegreerde multisectoriële aanpak van het obesitasprobleem uiteindelijk echt zoden aan de dijk zal zetten.

Over onderwijs

Ik ga niet zoveel over het onderwijs zeggen, hoewel ik daar een heel groot deel van mijn tijd aan heb besteed en goed onderwijs aan studenten uiteraard een topprioriteit moet zijn voor een universiteit. Maar misschien toch dit: ik heb in mijn 25-jarige onderwijscarrière een flink aantal ingrijpende curriculumherzieningen meegemaakt. Ik heb me er soms over verbaasd hoe snel de ideeën - al dan niet ingegeven door bezuigingen - konden veranderen, waardoor de ene herziening nauwelijks achter de rug was als de andere al weer ingezet werd, waarbij opeenvolgende herzieningen soms haaks op elkaar stonden. Telkens werd dat weer met de allerbeste bedoelingen gedaan en hebben betrokkenen zich er steeds voor ingezet om de herzieningen tot een succes te maken. Toch heb ik het gevoel dat wat meer rust om ingezette veranderingen volledig tot ontplooiing te laten komen wenselijk geweest zou zijn. Hoe het ook zij, ik hoop van ganserharte - en misschien wel tegen beter weten in - dat de curriculumherziening die nu gaande is binnen de bacheloropleidingen Gezondheidswetenschappenen en Biomedische Wetenschappen de gehoopte resultaten zal opleveren, zodat het daarna eens een poosje echt rustig kan blijven op het onderwijsherzieningsfront.

\section{Dankwoord}


Ik ben aan het eind gekomen van dit afscheidscollege. Zoals u waarschijnlijk begrepen hebt uit het feit dat ik nog een aantal onderzoeksprojecten heb lopen, betekent dat niet dat ik de universiteit al volledig verlaat, want die lopende projecten zal ik de komende jaren nog afmaken. Ik heb de universiteit (meestal) als een bijzonder prettige werkomgeving ervaren met gelukkig een grote vrijheid om naar eigen inzicht te handelen en je talenten te ontwikkelen. Ik ben de universiteit en met name de faculteiten, de onderzoeksinstituten en vakgroepen waarbinnen ik dat heb kunnen doen heel dankbaar voor die vrijheid.

Ik heb de afgelopen jaren met enorm veel mensen op een heel plezierige manier samengewerkt. Ik kan ze uiteraard niet allemaal bij naam noemen want dan wordt het veel te laat en bovendien zou ik zeker mensen vergeten.

Een paar mensen ga ik wel specifiek bedanken: Rob Binkhorst van de Universiteit van Nijmegen bij wie ik mijn promotieonderzoek heb gedaan; Heinz Rahn die me de kans gaf te beginnen bij de vakgroep Farmacologie van de toen kersverse Medische Faculteit van de Rijksuniversiteit Limburg; Harry Struijker Boudier die me de mogelijkheid gaf bij Farmacologie te blijven terwijl ik onderzoek deed voor het Instituut Sportgeneeskunde Limburg waar Frans Verstappen de drijvende kracht was; Wim Saris die me vervolgens na 10 jaar mijn eerste vaste aanstelling bezorgde bij de vakgroep Humane Biologie van de toenmalige Faculteit Gezondheidswetenschappen; en Ellen Blaak met wie ik samen de onderzoekslijn waar ik vandaag de belangrijkste resultaten van heb laten zien heb opgestart. Vaak zijn we met elkaar verward (Baak en Blaak), maar dat heeft ons volgens mij uiteindelijk geen van beiden windeieren gelegd. Dank aan alle aio's, onderzoeksassistenten, analisten, diëtisten, secretaresses en studenten zonder wier harde werken dit alles niet tot stand zou zijn gekomen. Dank aan de mensen van het NUTRIM bureau en van Bureau Onderwijs van de FHML. Uiteraard 
ben ik de allermeeste dank verschuldigd aan de honderden vrijwilligers die niet alleen hun tijd hebben gegeven aan de wetenschap, maar zich ook aan diëten hebben gehouden, pillen hebben geslikt, zich hebben ingespannen, vragenlijsten hebben ingevuld, en hun bloed, zweet, vet, spier, adem en wat al niet meer hebben afgestaan. Zonder hen zou de wetenschap niet verder komen. Rob Binkhorst vroeg mij ooit in mijn sollicitatiegesprek in Nijmegen of ik van mensen hield. Op dat moment vond ik dat een rare vraag, maar ik besef nu maar al te goed hoe belangrijk het is dat je van mensen houdt als je onderzoek met mensen doet.

Het laatste woord van dank is voor Bart, Gerben en Cindy, Laurens, Yara en uiteraard kleindochter Floor. Ik ben ongelofelijk trots op jullie. Jullie zijn stuk voor stuk fantastische mensen en, nog een beetje in Sinterklaassfeer, ik had me geen beter thuisfront kunnen wensen.

Ik heb gezegd. 
[1] Ter Schegget J, van den Bosch $H$, van Baak MA et al. The synthesis and utilization of dCDP-diglyceride by a mitochondrial fraction from rat liver. Biochim Biophys Acta 1971; 239:234-242.

[2] van Baak MA, Binkhorst RA. Oxygen consumption during outdoor recreational cycling. Ergonomics 1981; 24:725-33.

[3] Teuscher D, Bukman AJ, van Baak MA et al. Challenges of a healthy lifestyle for socially disadvantaged people of Dutch, Moroccan and Turkish origin in the Netherlands: a focus group study. Critical Public Health 2014.

[4] Aller EE, Larsen TM, Claus $\mathrm{H}$ et al. Weight loss maintenance in overweight subjects on ad libitum diets with high or low protein content and glycemic index: the DIOGENES trial 12-month results. International Journal of Obesity 2014; Mar 28. doi: $10.1038 /$ ijo.2014.52.

[5] Speakman JR, Levitsky DA, Allison DB et al. Set points, settling points and some alternative models: theoretical options to understand how genes and environments combine to regulate body adiposity. Dis Model Mech 2011; 4:73345.

[6] Halaas JL, Gajiwala KS, Maffei M et al. Weight-reducing effects of the plasma protein encoded by the obese gene. Science 1995; 269:543-6.

[7] van Aggel-Leijssen DP, van Baak MA, Tenenbaum $R$ et al. Regulation of average $24 \mathrm{~h}$ human plasma leptin level; the influence of exercise and physiological changes in energy balance. Int J Obes Relat Metab Disord 1999; 23:151-8.

[8] Blaak EE, Van Baak MA, Kemerink GJ et al. Beta-adrenergic stimulation of energy expenditure and forearm skeletal muscle metabolism in lean and obese men. Am J Physiol 1994; 267:E306-15.

[9] Schiffelers SL, Saris WH, Boomsma F, van Baak MA. Beta(1)- and beta(2)Adrenoceptor-mediated thermogenesis and lipid utilization in obese and lean men. J Clin Endocrinol Metab 2001; 86:2191-9.

[10] Blaak EE, van Baak MA, Kester AD, Saris WH. Beta-adrenergically mediated thermogenic and heart rate responses: effect of obesity and weight loss. Metabolism 1995; 44:520-4.

[11] Oomen JM, van Rossum CT, Hoebee B et al. Beta2-adrenergic receptor polymorphisms and salbutamol-stimulated energy expenditure. J Clin Endocrinol Metab 2005; 90:2301-7.

[12] Vosselman MJ, van der Lans AA, Brans B et al. Systemic beta-adrenergic stimulation of thermogenesis is not accompanied by brown adipose tissue activity in humans. Diabetes 2012; 61:3106-13.

[13] Rosenbaum M, Leibel RL. 20 years of leptin: role of leptin in energy homeostasis in humans. J Endocrinol 2014; 223:T83-96.

[14] Roujeau C, Jockers R, Dam J. New pharmacological perspectives for the leptin receptor in the treatment of obesity. Front Endocrinol (Lausanne) 2014; 5:167.

[15] Kwak L, Kremers SP, Candel MJ et al. Changes in skinfold thickness and waist circumference after 12 and 24 months resulting from the NHF-NRG In Balance-project. Int J Behav Nutr Phys Act 2010; 7:26.

[16] Roumen C, Feskens EJ, Corpeleijn E et al. Predictors of lifestyle intervention outcome and dropout: the SLIM study. Eur J Clin Nutr 2011; 65:1141-7.

[17] Bray GA. Obesity: basic considerations and clinical approaches. Dis Mon 1989; 35:449-537.

[18] Puzziferri N, Roshek TB, 3rd, Mayo HG et al. Long-term follow-up after bariatric surgery: a systematic review. JAMA 2014; 312:934-42.

[19] Franz MJ, VanWormer J], Crain AL et al. Weight-loss outcomes: a systematic review and meta-analysis of weight-loss clinical trials with a minimum 1-year follow-up. J Am Diet Assoc 2007; 107:1755-67.

[20] Look AHEAD Research Group. Eight-year weight losses with an intensive lifestyle intervention: the Look AHEAD study. Obesity (Silver Spring) 2014; 22:513. 
[21] Casazza K, Fontaine KR, Astrup A et al. Myths, presumptions, and facts about obesity. N Engl J Med 2013; 368:446-54.

[22] Claessens M, van Baak MA, Monsheimer S, Saris WH. The effect of a low-fat, high-protein or high-carbohydrate ad libitum diet on weight loss maintenance and metabolic risk factors. Int J Obes (Lond) 2009; 33:296-304.

[23] Larsen TM, Dalskov SM, van Baak M et al. Diets with high or low protein content and glycemic index for weight-loss maintenance. N Engl J Med 2010; 363:2102-13.

[24] Teunissen-Beekman KF, Dopheide J, Geleijnse JM et al. Protein supplementation lowers blood pressure in overweight adults: effect of dietary proteins on blood pressure (PROPRES), a randomized trial. Am J Clin Nutr 2012; 95:966-71.

[25] Johansson K, Neovius M, Hemmingsson E. Effects of anti-obesity drugs, diet, and exercise on weight-loss maintenance after a very-low-calorie diet or lowcalorie diet: a systematic review and meta-analysis of randomized controlled trials. Am J Clin Nutr 2014; 99:14-23.

[26] McKinsey Global Institute. Overcoming obesity: an initial economic analysis. In: 2014. 